\title{
'Youth' Making Us Fit: on Europe as operator of political technologies
}

\author{
ULF OLSSON \\ University of Stockholm, Sweden \\ KENNETH PETERSSON \\ Linköping University, Sweden \\ JOHN B. KREJSLER \\ Aarhus University, Denmark and \\ Kristianstad University College, Sweden
}

\begin{abstract}
This article problematizes the construction of youth as a 'driving force' in the contemporary configuration of the European Union (EU) as an educational and political space. The study draws empirical nourishment out of documents that are central to the ongoing formation of the Union, be it White Papers, scripts or memos concerning political arenas such as youth and education policies and the Bologna process. Theoretically the article draws on insights from post-Foucauldian traditions with a focus on mentalities, subject constructions, technologies and practices operating within the ongoing governmentalization of Europe. Central questions are 'who' and 'what' the problematization of youth as political technology is about. Drawing on homologies in the coding of citizen, independent of age, the authors claim that problematization of youth is directed to all of us. We are all, in the name of youth, expected to constantly 'adapt' ourselves in compliance with the aim of the Lisbon process. Furthermore, as the Union itself is coded in a similar way, we may even claim that the EU, literally speaking, appears as a youth project in itself. Thus, the notion that youth can be seen as political rationality that becomes a powerful driving force in the ongoing European project.
\end{abstract}

\section{Introduction}

It is time now to regard youth as a position force in the construction of Europe rather than as a problem. (COM, 2001, p. 5)

This quotation is just one among innumerable expressions which indicate that the issue of youth has moved up on the political agenda concerning contemporary European integration aspirations. This article particularly deals with the various conceptions of youth as they take shape on the arenas of education and youth policy. One example of this is represented by the European Commission's White Paper on the envisaged future 'youth policy' for the European Union (EU) as a whole. With reference to the expansion of the Union and other current political projects, emphasis is placed on the importance of 'The European Union and its forms of governance being developed in cooperation with its citizens' and especially those 'who are going to be at the helm in the future' (COM, 2001, p. 5), i.e. youths.

It is on the ground, where young people can see the results of their personal commitment, that active citizenship becomes a reality. It is by taking part in the life of schools, neighbourhoods, local districts or associations that young people can acquire the experience and the confidence they need to go a step further, either now or later, in public life including at European level. It is by throwing themselves into social activities which are open to all, without any form of 
discrimination, that young people can make their contribution to a more solidarity-conscious society and live citizenship to the full. (COM, 2001, p. 4)

Youth is thus given a prominent place in the plan for this future Europe. This way of thinking, according to the White Paper, is entirely in line with the wishes of European youths themselves. The fact is, according to the Commission, that they have expressed themselves 'loud and clear' that they desire to be considered as 'fully fledged conversation partners' so they can 'influence the debate on the way it develops', and thus 'contribute to building the EU' (COM, 2001, p. 5).

The Union's narrative of young people is more or less the inverse to the narrative of the European citizen at large, i.e. the European project has still not 'succeeded in attracting the appropriate level of interest and the full support of the people of the Union' (COM, 2003, p. 4). In a situation where there are concerns that the citizens of Europe are not considered sufficiently interested in contemporary integration projects, high expectations are placed on Europe's youth. Similar conceptions of the role of youth in the building of an envisaged future Europe can be found in education policy, i.e. one of the key arenas where those who 'are going to be at the helm in the future' are expected to prepare for this transfer. Among the large number of documents concerned with the Bologna process, for instance, there is considerable attention to the accentuation on youth as a central driving force to implement the targets of the Lisbon process to make Europe the most dynamic and competitive knowledge-based economy in the world (COM, 2007, p. 2). As the Bologna process proceeds, an ever more closely unified conception of youth, learning, knowledge and future appears.

Similar modes of thought permeate the Commission's document on common European principles for teachers, in particular future teachers, competences and qualifications (Buchberger et al, 2000; COM, 2005).

Teachers play a crucial role in supporting the learning experience of young people and adult

learners. They are key players in how education systems evolve and in the implementation of the reforms which can make the European Union the highest performing knowledge-driven

economy in the world by 2010. (COM, 2005, p. 1)

Thus, the subjects of education policy, as of youth policy - youth, pupils, students, and future teachers - are expected to play a vital role in shaping the future Europe. Consequently youth and education as they appear in EU documents are not just about policies directed towards young people by means of the creation of societal arenas where they can be educated or are given a voice and where they are being listened to. In the final analysis, it is about political mobilization and the governance of the future development of the European Union, in this case by and through youth.

This article therefore, does not focus on youth and education policies understood as policies aimed at specific population groups that we usually categorise as youth or the like. Instead our focus targets the construction of youth as a 'driving force', or as energy that aims at extending and intensifying European integration (COM, 2001, p. 3). The article scrutinizes how the construction of the subject of youth as discursive practices and governmental technologies is made possible within the framework of contemporary thinking on Europe. By implication, the purpose is not to discuss youth and education policy. The purpose is rather to make problematic - in a Foucauldian sense - the fabrication of the subject of youth as a political technology in the contemporary configuration of Europe as political and economic space.

A key issue in this context concerns the 'who' that problematization of youth as a political technology is all about. From a governmentality perspective, it is not self-evident that the answer to 'the who question' is young people. For, according to the Commission's statements, the identification, dispositions and capacities required, already exist among Europe's youth. According to such statements - as previously quoted - youths are not forced to participate and to be active. They already wish to be considered fully fledged partners in contemporary European discourse and in shaping the future Europe.

Why begin to consider youth a 'driving force', when this driving force appears to exist already? Why not problematize European citizens in general as they, according to the narrative, are the problem by not giving full support to the Union? Or is the problematization of citizens in general included in the concept of youth as a floating signifier. Does the discourse about youthfulness direct itself, not only to special groups with physical or age related characteristics, but 
to all of us? Does this political problematization of youth have to do with the possibility that we all, in the name of youth, are expected to 'adapt' in compliance with the aims of the Lisbon process, that envisages the future Europe as the 'most competitive, dynamic, knowledge based economy in the world' with the possibility of sustainable economic growth with more and better job opportunities and a higher degree of social cohesion (European Council, 2000)? If youthfulness has to do with all of us, does that mean that the whole European Union project could be considered, literally, a kind of youth project?

Our study is based on empirical documents that in one way or another are central to understanding how the formation of contemporary and future Europe is conceived at key policy levels. We have mainly selected White Papers, scripts and memos from the EU Commission concerning political arenas such as youth and education policies, the Bologna process and lifelong learning.

Theoretically we draw on insights from post-Foucauldian traditions that pay particular attention to examining liberal versions of government; mentalities, subject constructions, technologies and practices that operate within contemporary political problematization of the European space (Walters, 2004; Dean, 2007). A more detailed presentation of our theoretical stance is followed by an analysis of the youth subject as it is being fabricated and mobilized in accordance with the contemporary will to govern Europe that permeates the narrative of the European Union.

\section{Problematization of Europe as Governmentalization}

Contemporary political as well as scientific narratives about Europe are often founded on essentialistic and unproblematized taken-for-granted assumptions that Europe and its citizens are already there, and have always been there, with special problems, needs, identities and future plans (Walters \& Haarh, 2005). Our point of departure differs from this kind of thinking. We claim that there is no Europe, no European citizen or any European identity to be assumed, or capable of being identified, beforehand. Throughout history a multitude of versions of Europe and European identities have existed depending, for instance, on the prevailing power and knowledge relationships, will to govern and will to truth, in different discursive and historical contexts (Nóvoa, 2002). Thus, like Walters \& Haahr (2005), we consider the European Union the latest but not necessarily the first or the last political project undertaken in terms of Europe. The version of Europe emerging today should be considered as one form of problematization of the contemporary/future from certain more or less specific interests. In line with Foucault (1988) we prefer the concept of problematization in preference to concepts such as construction. Or to use the language of Thomas Osborne:

Problematizations are not modes of constructing problems but active ways of positing and experiencing them. It is not that there is nothing 'out there' but constructions but that policy cannot get to work without first problematizing its territory. (Osborne, 1997, p. 174)

Europe as territory is being created and framed through the process of problematization itself. Our attention, therefore, is directed towards the ways that the contemporary is problematized, and towards the political spaces - in this case Europe - subjects and governmental technologies that appear as possible solutions to these kinds of territorial problematizations. In more concrete terms we seek to deepen understanding of the European integration by examining the reason and thoughts, i.e. the mentalities and rationalities, that permeate the particular contemporary project which has been named the Europe Union. In our analyses, we connect to Foucault's concept of governmentality, as this kind of analysis has the advantages that it does not require us to define political spaces like Europe and subjects as the individual, youth and citizen in advance. Instead, it becomes possible to scrutinize how these concepts and other floating signifiers acquire meaning within particular regimes of discourse and practice (Walters, 2004).

Governmentality studies pay particular attention to the relationships between governance, knowledge and political reason, in relation to questions like: How to govern those who are expected to govern themselves, and how much to govern (Walters \& Haahr 2005)? The analytical potential of governmentality analysis shows itself in its potential to bring together and unify studies of governance of self with governance of other entities such as the state, the nation, the local and the supranational. Notwithstanding this boundless openness to different types of governing 
processes, the majority of studies, with few exceptions, have focused mainly on political, social, cultural and economic processes within the political spaces of nation-states (Larner \& Walters, 2004). In other words, these studies have concerned themselves principally with a kind of biopolitical project that Foucault calls the governmentalization of the state (Foucault, 1994). In this study, however, attention is directed towards technologies, techniques and other procedures that go beyond states, i.e. supranational and global contexts and processes. Our attention being mainly concerned with so-called European integration, we principally deal with what Larner \& Waters (2004) call the Governmetalization of Europe, i.e. those processes of government that target the population within the European Union as a political space:

to speak of the governmentalization of Europe is to consider the practices, technologies or techniques that made it possible at a certain time for an organization to govern key dimensions of social and economic life in the name of Europe. (Walters, 2008)

The concept of technology commonly refers to material phenomena facilitating different kinds of practices in all areas of life. However, we operate with a different notion of technology; social technologies for the soul and for morality, focusing on the conduct and behaviour of the population and of individuals. Such technologies also include the technologies of the self that target the dispositions, capacities and conduct of the individual (Krejsler, 2006, 2007; Petersson et al, 2007).

We consider contemporary problematizations and constructions of youth to be technologies that operate within the political space of governmentalized contemporary Europe. The European project thus constitutes an interesting field for understanding forms and technologies of government that occur within as well as beyond the political spaces that are usually named nationstates. We thus wish to analyse political, educational and knowledge producing practices that - in the name of youth - contribute to make Europe possible and practicable. The latter aspect is particularly important, as practicality, i.e. the endeavour to emerge as practice in pursuit of certain real targets and effects, is the distinctive mark of political rationality (Hultqvist \& Petersson, 1995).

\section{Capacities and Dispositions: notions of the European youth subject in the making}

The youth subject is, thus, designed as a crucial technology in the governmentalization of Europe. Accordingly, how this youth subject is coded becomes an important issue. What capacities, dispositions and versions of themselves must youths display to be included in the overarching narrative of contemporary Europe as a dynamic knowledge society (see Popkewitz, 2008)? One of the settings where this coding is put into practice is in the goals of the EU programme named Youth adopted by the Council of Ministers in the year 2000. These goals strive:

- To promote the active contribution of youth to the building of Europe through participation across borders in exchanges within the Union or with third countries in order to promote a better understanding of European cultural diversity, and its fundamental and common values, as a contribution to the struggle against racism, anti-Semitism and xenophobia.

- To strengthen solidarity through the participation of youth in activities for public benefit across borders within the Union or third countries, especially countries, which have entered into agreements of co-operation with the Union.

- To encourage the initiative, enterprise and creativity of youth so that they can play an active role in society and at the same time increase their awareness of the value of an informal European educational experience.

- To strengthen co-operation in matters concerning youth by promoting the exchange of good practice, education of individuals who work with youth/youth leaders, and to formulate creative measures to be taken at union level. (Council of Ministers, 2000)

In these goals the floating signifier 'youth' is coded as being or becoming an active border crosser, participatory, full of initiative, enterprising, creative, feeling solidarity, and as being boundlessly equipped with an understanding of the cultural diversity and the common values assumed to exist in Europe. 
Similar ways of thinking appear within the field of education. Universities are expected to stimulate an 'entrepreneurial mindset amongst students and researchers' (COM, 2006, p. 7). European teachers are expected to help young people to acquire a 'spirit of entrepreneurship and innovation' and develop to become 'fully autonomous learners by acquiring key skills, rather than memorising information'. Furthermore, the learning subjects included in the narrative are expected to be 'globally responsible in their role as EU citizens', to show 'intercultural respect and understanding' and to be equipped with an ability to 'identify ... common values' (COM 2007, p. 4). In other words, the characteristics and capacities required by these subjects of education policy are largely the same as those required by the subjects of youth policy.

One of the dispositions being worked into the creation of the European youth subject is mobility and an ability to participate in exchanges across borders. This can take various forms, such as participation in 'publicly beneficial activities across borders or to undertake parts of their education abroad (Ungdomsstyrelsen, 2003, p. 132; see COM, 2001). This is also one of the main objectives of the Bologna process:

Ministers recognised that mobility of students and staff among all participating countries remains one of the key objectives of the Bologna Process. (European University Assocation, 2006, p. 7)

To enable the breaking down of barriers between universities in Europe, at least one-third of all students at advanced level and a fifth of all students at undergraduate level are, according to the targets, expected to spend at least one term abroad (EUA, 2006). Mobility in this respect does not mean travelling around in general; it is - so to speak - not the bodies but the brains that are in focus:

'Brain circulation' should also be promoted for European students, teachers and researchers who have decided to spend part of their working life outside Europe. (COM, 2006, p. 10)

Developing this society of learning in a knowledge economy, which is set to make the Union the most competitive and dynamic economy in the world, thus appears, first and foremost, to concern brains, knowledge and competences, which citizens are expected to circulate in boundless mobility. This is in line with Tony Blair's statement in 2006 when he claimed that Europe cannot compete in a global knowledge economy on the basis of low-paid skills, but only on the basis of intelligence, innovation and creativity (COM, 2007). This ordering of things and its demands for creativity and innovation chisels out European youth as educative and lifelong learning subjects (COM, 2009):

Making lifelong learning a reality and promoting creativity and innovation are two of the major priorities proposed by the European Commission in its strategic vision for education and training until 2020. (COM, 2009, p. 4)

Lifelong learning is expected to be the key to personal and professional development, economic growth and success for individuals as well as society. Lifelong learning and its subjects, as well as the expectations of innovative ability and creativity as anticipated outcomes of these, emerge more or less as the solution to the risks, challenges and uncertainties that Europe faces in a world of global competition.

Within the youth programme the subject is constructed as a lifelong learner equipped with abilities to grasp the breadth and importance not only of education in the usual sense, but of nonformal and informal learning as well:

The advantage of non-formal learning lies mainly in its voluntary and often self-organised nature, its flexibility, the possibilities of participation, the 'right to make mistakes', the closer link to young people's interests and aspirations. (COM, 2001, p. 34)

Non-formal learning is seen as voluntary, self-organized and in line with young people's own desires. It is inscribed in the European concept of lifelong learning that is considered as vital for the objective to realize the goals of the Lisbon process. The voluntariness and the aspirations of young people become political tools for learning that are adapted to the ever ongoing process of change and uncertainty inscribed in the contemporary narrative of Europe. Thus, the voluntariness, flexibility and aspirations become technologies for producing the ability to adapt in the name of young people's interests and aspirations.

We deal with a kind of cognitive learning and training destined to produce subjects who are able to successfully meet the challenges that the European project, according to the narrative, 
encounters in a dynamic, uncertain and competitive world. This kind of learning, however, is not only cognitive, but perhaps most of all political, since it is a learning that is governed in line with certain political aspirations and targets (see Dale, 2004, p. 189). Lifelong learning and the version of youth that is included in the lifelong learning concept becomes a biopolitical apparatus of security, which is not linked to military defence of borders, but to discourses about the welfare, well-being and education of the population in a cross-national European political space (Foucault, 1994).

\section{The Boundless European vs. the Locally Rooted National}

As previously shown, the desired subject is constructed as one who manifests his/her loyalty by becoming boundless, mobile, interculturally respectful and globally responsible. The subject included in the European project is thus coded with an ability to lift him or herself over and above provincial and local contexts. This subject develops an identity beyond boundaries, an identity imbued with hope concerning a successful future for Europe (see Popkewitz, 2008). In the evaluation of the European Youth programme, which is expected to strengthen the feeling of solidarity through youth's 'participation in boundless and publicly beneficial activities', this subject appears oddly absent due to the simple fact that the project in question pushes forward the opposite, i.e. strengthens a sense of the 'local' and 'indigenous'. The youths participating in the project have simply not 'discovered' the fundamental values of the European narrative (Ungdomsstyrelsen, 2003, p. 106):

Youth, who have been involved in youth initiatives, generally find it difficult to describe the European dimension of their projects. They furthermore do not give expression to their sense of belonging with Europe having increased through participation in the EU Youth Programme.

According to the evaluation it would appear that the dream of a European boundless youth subject with a sense of belonging to Europe has been dashed, and that the 'local' subject excluded from the project emerges as the victor. This apparent failure, however, does not necessarily constitute a failure seen from a governmental perspective, as the presumably excluded subject is conspicuously included and highlighted in the evaluation document:

Thanks to the contributions made to the creation of new meeting places and activities of the youth initiatives it is however more than likely that the sense of local belonging between different groups of youth has increased. (Ungdomsstyrelsen, 2003, p. 106)

The expectations of the capacities that European youth warrant for boundless cooperation, thus, do not appear within the framework of the project as such. Rather, what we glimpse is a subject equipped with a disposition towards a sense of belonging at a local level. Also this subject is, as we can see in the quotation above, described in inclusive terms.

What appears as a paradox rather reveals the disposition of the youth subject to belong, at a boundless European level as well as at a locally framed and rooted level. The subject represented by European integration thus emerges as a European who is able to lift him or herself over and above local contexts while simultaneously remaining locally rooted.

However, the local context that the subject is expected to liberate him or herself from is not, from a discursive point of view, the same as the local context within which the subject is expected to be rooted. The excluded local and the included local are operating within two different discourses and governmental rationalities. The first operates within a discourse of the governmentalization of the state and the second within a discourse of the governmentalization of Europe. Thus, 'belonging locally' evokes a sense of belonging, which is organized from a different locus than the nation-building that we associate with the era of the welfare state. Something has apparently happened with the political rationality in so far as the local and the national emerging from an EU discursive framework is based on a different rationality of governance than the local and national we associate with the nation-building national projects of the welfare state. The narrative of the European Union thus encourages us to frame the actualization of ourselves within a greater 'imagined community'. This imagined community does not liberate us from conceptions about the local. It rather reframes thinking about the local within the question of governing Europe (see Anderson 1992). 


\section{Inventing a European Identity}

In the document about Common European Principles for Teacher Competences and Qualifications it is emphasized that teachers play a crucial role not only for young people's learning but for the lifelong learning of adults as well (COM, 2005). All citizens are expected to participate in lifelong learning and are thus constructed as well as constructing themselves as future-oriented subjects (COM, 2009). Similarly, the mobility programme is concerned not only with young people but also with adult students and citizens in general as a workforce (Lifelong Learning, 2009). According to the programme Europe for Lifelong Learning (2009), the Union is faced with the challenge to create a European labour market in which well-educated and trained citizens can take their qualifications across borders'.

Thus, in principle all European citizens are fabricated as potentially mobile lifelong learning subjects. Moreover, the capacities and dispositions inscribed in the youth subjects are also inscribed in adult subjects as teachers and adult learners:

Pupils, students, adult learners, teaching staff, trainers and trainees have great potential as drivers of creativity and innovation. (COM, 2009, p. 4)

Bearing in mind that all citizens included in the European project are coded in a similar way as youth subjects, it seems reasonable to conceive of the concept of youth as concerning us all independently of age and status. We are thus all urged to adapt, i.e. to form an opinion as to who we are and who we ought to become. The aspirations of governance relating to youth are thus not primarily directing themselves to a new generation but to a new human being to be included in a European project in the making.

This youthful European subject can thus be considered a possible answer to the issue of finding and strengthening a sense of European identity (COM, 1993; Belamy \& Waeleigh, 2001; Johanssson, 2007). Identities thus emerge as something that is invented and manufactured within prevailing power and knowledge conditions and problematizations of contemporary societies. The youthfully boundless as well as locally rooted subject that appears in the documents can thus be considered as an invention of a European identity operating as a governmental technology in the contemporary problematizations and construction of the European space.

The expectations to become boundless and locally rooted are not only directed towards individual subjects, but also towards individual member states and the Union as a whole. For instance, the Bologna processes urge member states not only to promote their own higher education systems internationally, but also to take responsibility for and promote the whole European Higher Education Area (Rauhvargers et al, 2009). Furthermore, this is not the only homology comparing the description of individual subjects and collective subjects as single member states of the Union and the Union as a whole:

The European project is itself young, still forming and still being debated. If it is to make progress, it needs ambition and enthusiasm, and commitment on the part of young people to the values on which it is based. (COM, 2001, p. 4)

According to the quotation, the European project is itself something young, unfinished, in the making. The project itself is thus coded in terms of the same dispositions that are inscribed in the citizen of the Union. In a similar way concepts such as lifelong learning and knowledge development are coding not only the citizen but also single member states within the Union and thus the Union as a whole.

It aims to help countries identify innovation and good policy practice, and to learn from each other. (Europe for Lifelong Learning, 2007)

Not only individual subjects but also separate nations are constructed as learning subjects, expected to learn from each other. Every single country in the Union and accordingly the Union as a whole are considered as constantly learning subjects representing a 'vibrant knowledge society' (COM, 2007, p. 21). Drawing on the homologies in the coding of citizen and the Union as a whole, it seems plausible to consider the total European Union project a youth project.

The plausibility of this analysis becomes even clearer when the Union is envisaged as the most expansive and innovative region of the future. According to the European University Association, higher education has stagnated in nearly all of Europe, despite the commitment to the 
Lisbon strategy. However, another fast growing political space has met with the challenge of the future in a more successful way: 'China, on the other hand, has fully adopted the Lisbon objectives' (EUA, 2006, p. 3).

If youth operates as a technology of hope within the narrative of the European Union, its opposite, stagnation, operates as the threat. The Commission report Taking the European Knowledge Society Seriously refers to Tony Blair stating that the competition from China must be met with 'intelligence', 'innovation' and 'creativity', i.e. the capacities of the youth subject (COM, 2007, p. 14). Thus, in order to take the lead in 'the global race' for economic survival (COM, 2007, p. 13), Europe must become one of the youngest political spaces on a global arena.

\section{Conclusion}

In a political climate where citizens of Europe are not considered sufficiently interested in contemporary European integration, high expectations are placed on Europe's youth. Thus, a central question is 'who' and 'what' this problematization of youth as political technology is about. As the individual subjects, independent of age or physical characteristics, are coded in a similar way, we claim that the contemporary problematization of youth is directed to us all. In the name of youth, we are all expected to constantly 'adapt' to the aims of the Lisbon process. The aspirations of governance relating to youth are thus not primarily directing themselves to a new generation but to a new human being to be included in a new society, the European project in the making. Furthermore, drawing on the homologies in the coding and fabrication of citizen as well as the Union as subjects, it can be said that the EU appears as a youth project in itself. Thus youth can be seen as a figure of political rationality that fabricates a new human being adapted to the contemporary European political narrative. Seen from this perspective, youth becomes the bearer of a number of things. At an overarching level, youth becomes a formula which enables us to see the EU as an entity in the making and simultaneously as something which already exists.

Concerning our employment of concepts like 'construction' and 'fabrication' of subjects, individual as well as collective, we draw attention to two overlapping dimensions of government that are woven into the problematization of Europe itself (Petersson et al, 2007). One dimension is concerned with construction or fabrication considered as fiction. By describing subjects as autonomous, creative, mobile and boundless, fictions are created by means of which we can rethink and reshape aspects of the world that we want to direct attention to. Initially this is mainly about a way of thinking and not about ways of handling 'real' or 'material' things. The other dimension, however, concerns what the constructed fictions do in the world, for instance, through production of indicators that measure whether we adjust ourselves in compliance with the fictions. The fictions thus acquire a dimension of power that operate as means, which have assumed life by being directed towards real and material subjects that are to be governed, administered, organized, educated and evaluated. Thus, the notion of youth in EU documents operates as a political rationality and technology in the creation of contemporary and future European identities and community. Youth as a political rationality becomes a powerful figure of thought and a driving force 'making us fit' for the ongoing European project.

\section{References}

Anderson, B. (1992) Den föreställda gemenskapen. Reflexioner kring nationalismens ursprung och spridning. Göteborg: Daidalos.

Belamy, R. \& Waeleigh A. (2001) Introduction: The Puzzle of EU Citizenship, in R. Bellamy \& A. Warleigh (Eds) Citizenship and Governance in the European Union. London: Continuum.

Buchberger, F., Campos, B., Kallos, D. \& Stephenson, J. (Eds) (2000) Green Paper on Teacher Education in Europe. High Quality Teacher Education for High Quality Education and Training. Thematic Network on Teacher Education in Europe. Umeå: Umeå University.

COM. European Commission (1993) Green Paper on the European Dimension of Education. COM(93) 457. Brussels: European Commission.

COM. European Commission (2001) A New Impetus for European Youth. European Commission White Paper. $\operatorname{COM}(2001) 681$ final. Brussels: European Commission.

http: / / eur-lex.europa.eu/LexUriServ/site/en/com/2001/com2001_0681en01.pdf 
COM. European Commission (2003) The Successes of the Lisbon Strategy. Communication from the Commission: Education \& Training 2010. COM(2003) 685. Brussels: European Commission. http:/ / ec.europa.eu/education/policies/2010/doc/jir_council_final.pdf

COM. European Commission (2005) Common European Principles for Teacher Competences and Qualifications. European Commission: Directorate-General for Education and Culture. http: / / ec.europa.eu/education/policies/2010/doc/principles_en.pdf

COM. European Commission (2006) Delivering on the Modernisation Agenda for Universities: education, research and innovation. Communication from the Commission to the Council and the European Parliament. COM(2006) 208 final. Brussels: European Commission. http: / / ec.europa.eu/education/policies/2010/doc/comuniv2006_en.pdf

COM. European Commission (2007) Improving the Quality of Teacher Education. Communication from the Commission to the Council and the European Parliament. COM(2007) 392 final. Brussels: Commission of the European Communities. http:/ / ec.europa.eu/education/com392_en.pdf

COM. European Commission (2009) Creativity and Innovation: European success stories. Lifelong Learning Programme. Education and Culture, European Commission.

http: / / ec.europa.eu/dgs/education_culture/publ/pdf/ll-learning/creativity_en.pdf

Council of Ministers (2000) Decision No. 1031/2000/EG quoted here from: Ungdomsstyrelsen (2003) Tre år med EU-programmet Ungdom. En studie kring programmets effekter åren 2000-2003. Stockholm: Ungdomsstyrelsens Skrifter 2003:7. [The Swedish National Board for Youth Affairs (2003) Three Years with the EU Youth Program. Stockholm: Swedish National Board for Youth Affairs].

Dale, R. (2004) Forms of Governance, Governmentality and the EU's Open Method of Coordination, in W. Larner \& W. Walters (Eds) Global Governmentality: governing international spaces. London: Routledge.

Dean, M. (2007) Governing Societies: political perspectives on domestic and international rule. Maidenhead: Open University Press.

European University Association (EUA) (2006) The Contribution of Universities to Europe's Competitiveness. Speech of European University Association President Prof. Georg Winckler to the Conference of the European Ministers of Education, Vienna, 16-17 March.

http:/ / www.Eua.be/eua/jsp/en/upload/EUA_Winckler_Speech_160306.14250329I615.pdf (accessed 19 November 2009).

European Council (2000) Presidency Conclusion, Lisbon European Council, 23 and 24 March.

Europe for Lifelong Learning (2007)

http:/ / ec.europa.eu/dgs/education_culture/publ/pdf/ll-learning/europe_en.pdf

Felt, U. (2007) Taking European Knowledge Society Seriously. Brussels: European Commission.

Foucault, M. (1988) On Problematization, History of the Present, 4, 16-17.

Foucault, M. (1994) Governmentality, in D. Faubion (Ed.) Michel Foucault. Essential Works of Foucault 1954-1984 (vol. 3), Power. London: Penguin.

Hultqvist, K. \& Petersson, K. (1995) Postmoderna strömningar och den politiska rationaliteten, in Lars Dahlgren \& Kenneth Hultqvist (Eds) Seendet och seendets villkor. Stockholm: HLS Förlag.

Johansson, J. (2007) Learning To Be(Come) a Good European: a critical analysis of the official European Union discourse on the European identity and higher education. Linköping Studies on Arts and Science, 417. Department of Management and Engineering, Linköping University.

Krejsler, J. (2006) Education and Individualizing Technologies: exploring new conditions for producing individuality, in T.S. Popkewitz, U. Olsson, K. Petersson \& J. Kowalczyk (Eds) The Future Is Not What It Appears To Be: pedagogy, genealogy and political epistemology, pp. 193-212. Stockholm: HLS Förlag.

Krejsler, J. (2007) Discursive Strategies that Individualize: CVs and appraisal interviews, International Journal of Qualitative Studies in Education, 20(4), 473-490. http: / / dx.doi.org/10.1080/09518390601176440

Larner, W. \& Walters, W. (Eds) (2004) Global Governmentalities: governing international spaces. London: Routledge.

Lifelong Learning Program (2009) Dissemination and exploitation of results. http:/ / ec.europa.eu/education/dissemination-and-exploitation-of-results/doc76_en.htm

Nóvoa, A. (2002) Ways of Thinking about Education in Europe, in A. Nóvoa \& M. Lawn (Eds) Fabricating Europe: the formation of an education space. Dordrecht: Kluwer.

Osborne, T. (1997) On Health and Statecraft, in A. Peterson \& R. Bunton (Eds) Foucault, Health and Medicine. London: Routledge.

Petersson, K., Olsson, U. \& Popkewitz, T. S. (2007) Nostalgia, the Future, and the Past as Pedagogical Technologies, Discourse, 28(1), 49-67. http:/ / dx.doi.org/10.1080/01596300601073598 
Ulf Olsson et al

Popkewitz, S. T (2008) Cosmopolitanism and the Age of School Reform. Science, Education, and Making Society by Making the Child. London: Routledge.

Rauhvargers, A., Deane, C. \& Pauwels, W. (2009) Bologna Process Stocktaking Report. http:/ / www.ond.vlaanderen.be/hogeronderwijs/bologna/conference/documents/Stocktaking_report _2009_FINAL.pdf

Ungdomsstyrelsen (2003) Tre år med EU-programmet Ungdom. En studie kring programmets effekter åren 2000-2003. Stockholm: Ungdomsstyrelsens Skrifter 2003:7 [The Swedish National Board for Youth Affairs (2003) Three Years with the EU youth program. Stockholm: Swedish National Board for Youth Affairs].

Walters, W. (2004) The Political Rationality of European Integration, in W. Larner \& W. Walters (Eds) In Global Governmentality: governing international spaces. London: Routledge.

Walters, W. (2008) Globalization and Power: governmentalization of Europe. An Interview with William Walters, Foucault Studies, 5.

Walters, W. \& Haarh, J.H. (2005) Governing Europe. Discourse, Governmentality and European Integration. London: Routledge.

ULF OLSSON is Associate Professor in Science of Education at the Department of Education in Arts and Professions, University of Stockholm. His research interests are global higher educational policy with a focus on governmentality and power relations. He is also doing research in the field of public health. Correspondence: Dr Ulf Olsson, UTEP, Campus Konradsberg, Stockholms universitet, SE-106 91 Stockholm, Sweden (ulf.olsson@utep.su.se).

KENNETH PETERSSON is Associate Professor in Communication Studies at the Department of Social and Welfare Studies, Linkoping University, Sweden. His research interests are educational policy and political philosophy with main focus on governmentality and educational reforms, science and research. Correspondence: Dr Kenneth Petersson, Department of Social and Welfare Studies, Linköping University/Campus Norrköping, Holmentorget 10, S-601 74 Norrköping, Sweden (kenpe@isv.liu.se).

JOHN BENEDICTO KREJSLER is Associate Professor at the School of Education at Aarhus University, Copenhagen, Denmark and Guest Professor at Kristianstad University College, Sweden. His research interests are higher education, teacher education and epistemology (poststructural and critical theory), as well as professional subjectivities and power relations in education. Correspondence: Dr John Benedicto Krejsler, Department of Education, School of Education, Aarhus University, Tuborgvej 164, DK-2400 Copenhagen NV, Denmark (jok@dpu.dk). 